\title{
TAFSIR TAHLILI: SEBUAH METODE PENAFSIRAN AL-QUR'AN
}

Rosalinda

Universitas Islam Negeri Sulthan Thaha Saifuddin Jambi

Rosalinda2205@yahoo.co.id

\begin{abstract}
Tafsir tahlili method is one of the method used by classical mufassir until now in interpreting al-Qur'an verses. This method emerges because of the necessity to the detail explanation of the instruction in the Al-Qur'an. This is also because of the increasing number of moslems along with the times, not only from the Arab nations but also from non-Arabic. Mufassir with tahlili method present an explanation of Al-Qur'an verses which are based on sequence of verses in the manuscripts (mushaf) of Al-Quran seen from any aspects, such as compatibility of one verse with another verse (munasabah al ayah), the cause of the descending verses, the meaning of verses globally, legal review contained, and additional explanation about qiroat, 'i'rab, and others.
\end{abstract}

Keywords: Tafsīr Tahlīlì , Method of Interpreting, Tahlīlī 


\section{Abstrak}

Metodetafsirtahlìlìmerupakansalahsatumetodeyangdigunakan oleh para mufassir klasik hingga kini dalam menjelaskan ayatayat al-Qur'an. Metode ini lahir karena kebutuhan terhadap penjelasan petunjuk al-Qur'an secara lebih rinci yang disebabkan kuantitas umat Islam yang semakin bertambah seiring perkembangan zaman, tidak hanya dari bangsa Arab saja tetapi juga non-Arab. Para mufassir dengan metode tahlīi menyajikan penjelasan ayat-ayat al-Qur'an berdasarkan urutan ayat dalam mushaf dilihat dari berbagai aspeknya, seperti munāsabah ayat, sebab turun ayat, makna ayat secara global, tinjauan hukum yang terkandung dan tambahan penjelasan tentang qira'at, i'rab dan lainnya.

Keywords: Tafsìr Tahlīili , Metode Tafsìr, Taḥlīì 


\section{A. PENDAHULUAN}

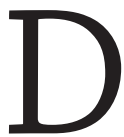
alam perkembangan tafsir al-Qur'an dari dulu hingga kini, secara umum para mufassir menggunakan metode tafsir yang beragam yang diklasifikasikan menjadi empat metode. Metode tafsir Ijmāli (global), metode tafsir Taḥlīì (analisis), metode tafsir Maudhü'i (tematik), dan metode tafsir Muqārin (perbandingan). ${ }^{1}$ Metode-metode tafsir tersebut memiliki keistimewan masing masing meskipun tidak dipungkiri bahwa terdapat juga kelemahan, kendati demikian penggunaan metodemetode tafsir tersebut disesuaikan dengan tujuan yang ingin diperoleh. ${ }^{2}$

Metode ijmāli berupaya menyajikan makna global dari ayatayat suci al-Qur'an secara ringkas dan mudah dimengerti. Para mufassir umumnya menghimpun ayat demi ayat sesuai urutan dalam mushaf atau satu surat kemudian ditafsirkan pokokpokok kandungan yang dimaksud dalam ayat-ayat tersebut secara global. ${ }^{3}$ Metode ini dianggap sebagai metode tafsir yang paling tua dibandingkan metode tafsir lainnya. Hal ini disebabkan karena mayoritas sahabat adalah orang Arab serta ahli bahasa Arab sehingga tidak kesulitan dalam memahami al-Qur'an, selain itu para sahabat mengetahui latar belakang turun ayat bahkan mereka ada yang menyaksikan secara langsung dan terlibat dalam situasi dan kondisi ketika ayat al-Quran turun. Bisa dikatakan bahwa para sahabat tidak membutuhkan penjelasan yang rinci dari nabi tetapi cukup dengan isyarat dan uraian sederhana. ${ }^{4}$ Metode ini memiliki keunggulan dibandingkan metode tafsir yang lain karena dianggap simpel dan mudah dimengerti serta tidak mengandung israiliyat dan mendekati bahasa al-Qur'an namun metode ini dianggap tidak memberi celah untuk melakukan analisis yang cukup dan

1 Badri Khaeruman, Sejarah Perkembangan Tafsir al-Qur'an, (Bandung: CV Pustaka Setia, 2004), h. 94.

2 M. Quraish Shihab, Kaidah Tafsir: Syarat, Ketentuan, dan Aturan yang Patut Anda Ketahui dalam Memahami Ayat-Ayat al-Qur'an, (Jakarta: Lentera Hati, 2013), h. 377.

3 Fariz Pari, “Tafsir sebagai Hermeneutika Islam: Kajian dan Terapan” dalam Pengantar Kajian al-Qur'an, Kusmana dan Syamsuri (ed), (Jakarta: Pustaka al-Husna Baru, 2004), h. 151.

4 Ahmad Syukri Saleh, Metodologi Tafsir al-Qur'an Kontemporer dalam Pandangan Fazlur Rahman, (Jakarta: Gaung Persada Press, 2007), h. 48. 
menjadikan petunjuk al-Qur'an bersifat parsial. Kitab-kitab tafsir yang merepresentasikan metode tafsir ini diantaranya Tafsir alQur'an al-Karìm karya Muhammad Farid Wajdi dan al-Wasiț karya tim majma' al-Buhuts al-Islamiyyah, Taisir al-Karìm ar-Rahmān fi Tafsīr kalām al-Mannan karangan Abdurrahman as-Sa'dy.

Selanjutnya metode taḥlīi atau metode analisis adalah suatu metode tafsir yang bermaksud menjelaskan ayat-ayat al-Qur'an dari segala aspeknya. ${ }^{5} \mathrm{Di}$ antara faktor yang mendorong munculnya metode ini adalah ketidakpuasan terhadap metode ijmāli dalam menafsirkan ayat al-Qur'an karena dianggap tidak memberi ruang dalam mengemukakan analisis yang memadai. Selain itu seiring perkembangan zaman maka kuantitas umat Islam semakin berkembang tidak hanya yang berasal dari bangsa Arab namun juga dari non-Arab. Perubahan dalam wacana pemikiran Islam pun tidak dapat dihindari dimana peradaban yang beragam dan tradisi non-Islam ikut berbaur dalam khazanah intelektual Islam serta mempengaruhi kehidupan umat. Oleh karena itu para pakar alQur'an berupaya menghidangkan penafsiran ayat al-Qur'an yang sesuai dengan perkembangan zaman dan kebutuhan masyarakat yang mejemuk. ${ }^{6}$ Jadi bisa disimpulkan munculnya tafsir tahlili karena kebutuhan umat Islam terhadap penjelasan yang rinci terhadap ayat-ayat al-Qur'an. Di antara karya tafsir dengan menggunakan metode tạhlīlì adalah karangan Ibn jarir al-Thabari "Jami' al-Bayān 'an Ta'wīl ayātil Qur'an" dan karangan al-Baghawi "Ma'alim al-Tanzill".

Kemudian metode tafsir muqārin atau metode tafsir perbandingan adalah sebuah metode penafsiran yang bersifat perbandingan dengan menyajikan penafsiran terhadap ayatayat al-Qur'an yang ditulis oleh mufassirin. Metode ini lahir karena kebutuhan untuk memahami ayat-ayat al-Qur'an yang kelihatannya mirip namun mengandung pengertian yang berbeda. Begitu juga ada hadits yang secara lahiriah bertentangan

5 Abd Hayy al-Farmawi, al-Bidāyah fi al-Tafsīr al-Maudhū'i: Dirāsah Manhajiyyah Maudhū'iyyah, terjemahan Rosihon Anwar, Metode Tafsir Maudhu'i Dan Cara Penerapannya. (Bandung: Pustaka Setia, 2002), h. 23.

6 Ahmad Syukri Saleh, Metodologi Tafsir al-Qur'an, h. 49. 
dengan ayat-ayat al-Qur'an. Metode ini memiliki keistimewaan diantaranya memberikan wawasan penafsiran yang lebih luas kepada para pembaca, toleransi terhadap perbedaan pendapat sehingga menghindari sikap ta'āsubiyah terhadap aliran tertentu, pendapat dan komentar terhadap suatu ayat menjadi lebih kaya, bagi mufassir akan termotivasi untuk mengkaji berbagai ayat, hadits serta pendapat mufassir lainnya, meskipun memiliki banyak keunggulan, metode ini juga memiliki kelemahan, di antaranya tidak sesuai jika dikaji oleh pemula karena pembahasannya teramat luas dan lebih dominan mengkaji penafsiran ulama terdahulu dibandingkan penafsiran baru. ${ }^{7} \mathrm{Di}$ antara kitab tafsir yang menggunakan metode tafsir ini adalah karangan al-Iskafi "Durrat al-Tanzīl wa Ghurrat al-Ta'wīl dan al-Burhān fi taujih Mutasyabah alQur'an karya al-Karmani.

Selanjutnya metode tafsir maudhü'i atau tematik merupakan metode penafsiran al-Qur'an dengan menghimpun seluruh ayat al-Qur'an yang memiliki tujuan dan tema yang sama, kemudian menyusunnya berdasarkan kronologi serta sebab turun ayat, kemudian mufassir menyajikan penjelasan dengan mengkaji seluruh aspek yang dapat digali agar mufassir dapat menyajikan tema secara utuh dan sempurna serta menarik kesimpulan. ${ }^{8}$ Kelebihan metode tafsir ini pada kemampuannya dalam menjawab tantangan zaman karena metode ini diformulasi untuk memecahkan persoalan dan disusun lebih sistematis sehingga lebih efesien waktu untuk dibaca dan tema-tema yang diangkat up to date sehingga menjadikan alQur'an tidak ketinggalan zaman dan menjadikan pemahaman lebih utuh. Kendati begitu, metode ini juga memiliki kekurangan dalam penjelasan ayat-ayat al-Qur'an yang sepotong-sepotong dapat menyebabkan kesan kurang etis terhadap ayat-ayat suci serta pembatasan pada tema-tema tertentu menjadikan pemahaman ayat terbatas. ${ }^{9}$ Di antara kitab-kitab tafsir yang menggunakan metode ini adalah Mar'ah fi al-Qur'an dan al-Insān karya 'Abbas Mahmud

\footnotetext{
7 Nasharuddin Baidan, Metodologi Penafsiran al-Qur'an, (Jakarta: Pustaka pelajar, 1998), h. 142-144.

8 Abd Hayy al-Farmawi, al-Bidāyah fi al-Tafsīr al-Maudhü'i, h. 52.

9 Nasharuddin Baidan, Metodologi Penafsiran al-Qur'an, h. 165-168.
} 
al-'Aqqad, Washaya Surat al-Isra' karangan Abd al-Hayy al-Farmawi.

Dalam tulisan ini dibatasi pembahasannya pada salah satu metode dari keempat ragam metode tersebut yaitu metode tafsir tahlīlì .

\section{B. METODE TAFSIR TAHLILI: PENGERTIAN DAN SEJARAHNYA}

Sebelum menjelaskan secara lebih rinci mengenai metode tafsir tahlīlì, penulis paparkan terlebih dahulu analisis terhadap beberapa term yang akan dibahas yaitu metode, tafsir dan tahlīlī. Metode dalam bahasa Arab disebut manhaj jamaknya manāhij yang diterjemahkan dengan jalan yang nyata. Di dalam surat alMa'idah ayat 48 disebutkan "untuk tiap-tiap umat di antara kamu kami berikan aturan dan minhaj (jalan yang terang). Sementara itu kata tafsìr merupakan bentuk taf'īl dari kata al-fasr yang berarti al-bayān wa al-kasyf (penjelasan dan penyingkapan). Tafsir adalah penjelasan tentang maksud firman Allah sesuai dengan kemampuan manusia. ${ }^{10}$ Menurut al-Zarkasyi (w.1392), tafsir merupakan suatu ilmu yang mengantarkan pada pemahaman terhadap kitab suci yang diturunkan pada nabi, penjelasan makna-maknanya, penggalian hukum-hukum dan hikmahnya.. ${ }^{11}$ Sedangkan alZarqani mengatakan tafsir adalah suatu ilmu yang mengkaji alQur'an dari segi tanda-tanda yang mengantarkan pada maksud Allah sesuai dengan kemampuan manusia. ${ }^{12}$ Jadi metode tafsir yang dimaksud adalah cara (langkah dan prosedur) yang digunakan oleh mufassir untuk menjelaskan ayat al-Qur'an. Dengan kata lain metode mengandung seperangkat kaidah dan aturan-aturan yang harus diperhatikan oleh para mufassir agar terhindar dari kesalahan-kesalahan dan penyimpangan-penyimpangan dalam

10 Muhammad Husain al-Dzahabi, al Tafsīr wa al-Mufassirūn, (Mesir: Dar al-Kutub al-Haditsah, 1976), Jilid. 1, cet. 2, h. 2.

11 Badr al-Din al Zarkasyi, al Burhān fi 'ulūm al-Qur'an (Beirut: Dar al-Kutub al 'Ilmiyahh,2008), Jilid 1, h. 13.

12 Abd al 'Azhim al-Zarqani, Manāhil al-Irfān fi 'ulum al-Qur'an, (Mesir: Mustafa al-Babi al-Habi, t.th), Jilid II, h. 6. 
menafsirkan ayat al-Qur'an. ${ }^{13}$ Sementara Tahlīlì berasal dari kata hallala-yuhallilu-tahlil yang diterjemahkan dengan "mengurai, menganalisis". ${ }^{14}$ Atau bisa juga berarti membuka sesuatu atau tidak menyimpang darinya. ${ }^{15}$ Atau membebaskan. ${ }^{16}$

Metode tafsir tahlīlì adalah salah satu metode tafsir yang sistematis karena kandungan al-Qur'an dijelaskan berdasarkan urutan ayat-ayat di dalam mushaf yang ditinjau dari berbagai aspeknya meliputi mufaradāt ayat, munāsabah ayat yaitu melihat hubungan antara ayat sebelum dan sesudahnya, sebab turun ayat, makna ayat secara global, tinjauan hukum yang terkandung dan tambahan penjelasan tentang qira'at, i'rab dan keistimewaan susunanan kata-kata pada ayat-ayat yang ditafsirkan serta diperkaya dengan pendapat imam mazhab. ${ }^{17}$ Metode tafsir tahlīlī disebut juga metode tajzi'iyah oleh Muhammad Baqir al-Shadr yang berarti "tafsir yang menguraikan berdasarkan bagian-bagian atau tafsir parsial". ${ }^{18}$

Metode tahlīlì memliki ciri tersendiri dibandingkan dengan metode tafsir yang lain. Berikut ini beberapa ciri-ciri dari metode tafsir tahlìlī : Membahas segala sesuatu yang menyangkut satu ayat itu. Tafsir tahlīin terbagi sesuai dengan bahasan yang ditonjolkannya, seperti hukum, riwayat dan lain-lain. Pembahasannya disesuikan menurut urutan ayat. Titik beratnya adalah lafadznya. Menyebutkan munasābah ayat, sekaligus untuk menunjukkan wihdah al-Qur'an. Menggunakan asbab nuzul ayat. Mufasir beranjak ke ayat lain setelah ayat itu dianggap selesai meskipun masalahnya belum selesai, karena akan diselesaikan oleh ayat lain. Persoalan yang

13 Supiana dan M.Karman, 'Ulumul Qur'an dan Pengenalan Metodologi Tafsir, (Bnadung: Pustaka Islamika, 2012), h.302.

14 Kata tahlīl diterjemahkan dengan analysis, analyzation, sementara tahlili diterjemahkan analytic (al). Lihat Rohi Baalbaki, al-Mawrid: A Modern Arabic-English Dictionary, (Beirut: Dar el 'Ilm lil Malayin, 1995), h. 290.

15 Ahmad bin Faris bin Zakariya Abul Husein, Mu'jam Maqāyis al-Lugah, Juz 2, (Beirut: Dar alFikr, 1979), h.20.

16 Muhammad bin Mukrim bin Manzur al Afriqy al Mishry Jamaluddin Abu Fadh, Lisān al'Arabi, Juz 11, (Beirut: Dar Sadir, 2010), h.163.

17 M. Quraish Shihab, Kaidah Tafsir, h. 378.

18 Muhammad Baqir al-Shadr, al Tafsir al Maudhū'I wa al-Tafsīr al-Tajzii fil Qur'anil karìm, (Beirut: Dar al Ta'aruf), h. 9. 
dibahas tuntas. ${ }^{19}$

Oleh karena itu metode taḥlìlì memiliki ciri khas dibandingkan metode tafsir yang lain yaitu penafsiran al-Qur'an dengan menggunakan metode tahlili merupakan penafsiran yang bersifat luas dan menyeluruh (komprehensif). Ciri yang paling dominan dari metode tafsir tahlìlì ini tidak hanya pada penafsiran al-Qur'an dari awal mushaf sampai akhir, melainkan terletak pada pola pembahasan dan analisisnya. ${ }^{20}$

Jika dilihat sejarah tafsir tahlīlī telah mengalami beberapa fase perkembangannya. Pada fase Awal tafsir ini hanya terdiri dari tafsiran atas kata-kata yang ambigu, aneh dan sulit. Tafsir tahlīlì terhadap kata-kata secara kebahasaan jarang sekali pada masa nabi karena tidak adanya kebutuhan masyarakat terhadap model tafsir seperti ini karena kemampuan bahasa mereka serta tidak bercampur dengan orang 'Ajam/non-Arab sehingga dikatakan bahwa pada era nabi belum ada tafsir secara kebahasaan. ${ }^{21}$

Kemudian pada fase kedua terjadi perluasan penafsiran besarbesaran. Hal itu menjadi kebutuhan primer bagi orang-orang yang baru masuk Islam, di mana mereka tidak menyaksikan langsung turunnya wahyu sehingga mucul kebutuhan terhadap tafsir bahasa sedikit demi sedikit hingga Islam menyebar di timur dan Barat. $^{22}$ Dalam perkembangan selanjutnya muncul tafsir tahlili setelah ilmu-ilmu keIslaman dibukukan. Dan muncul ilmu baru yang berkhidmat pada al-Qur'an al karim. Mulai analisa nash ayat al-Qur'an dengan bentuk yang lebih luas. Pada masa ini muncul kamus-kamus kebahasaan dan ilmu bahasa semakin berkembang seperti llmu nahwu, sharaf dan balaghah. Dengan demikian muncul penjelasan nash ayat al-Qur'an secara lebih luas dalam kerangka ilmu bahasa Arab yang bertujuan menjelaskan kata-kata yang asing/gharīb dalam al-Qur'an. Oleh karena itu ditulislah bukubuku yang menjelaskan makna kata dalam al-Qur'an secara khusus,

19 Rachmat Syafi'I, Pengantar Ilmu Tafsir, (Bandung: Pustaka SETIA, 2006), h. 241-242.

20 Zuailan, “Metode Tafsir Tahlili”, Diya al-Afkar, vol.iv, no.01, Juni 2016.

21 Muhsin Abd al-Hamid, Tathawwur tafsīr al-Qur'an, (Darul Kutub wa an-Nasyar, 1989), h. 17.

22 Musy'an Abdu Su'ud al-'Isawi, Tafsīr Tahlīli Tärikh wa Tathawur, (al-Mu'tamar al'Ilmi as-Tsani likuliyyatil 'Ulumul Insaniyyah, 2013), h. 65. 
misalnya kitab majāzul Qur'an yang ditulis oleh Abu 'Ubaidah (w.210 H) yang menafsirkan petunjuk kata al-Qur'an, menjelaskan qira'at-qira'at serta membahas gaya bahasa al-Qur'an dengan tafsir kebahasaan secara murni. Abu Ubaidah peletak pertama kajian balaghah al-Qur'an dari sisi tasybih, Kināyah, Taqdìm dan Takhìr. ${ }^{23}$ Selain itu muncul kitab ma'ānil Qur'an yang ditulis Abu Zakaria al-Fara' (W.207) yang kosentrasi pada lafaz dari segi I'rab dan derivasinya. Sementara Ma'ānil Qur'an karya Al-Akhfasy (w.215) lebih fokus pada al-Aswāt, al-Lughawiyah dan makhārijul Hurūf serta menjelaskan bentuk-bentuk qira'at yang beragam. Ia juga menjelaskan lafaz dan posisinya dalam kalam Arab secara bahasa, nahw, sharf dan balaghah. ${ }^{24}$ Kemudian terjadi perkembangan dalam analisa istinbat/penetapan hukum fiqh yang selanjutnya mereka mulai mengkaji nash al-Qur'an dari aspek fiqh. Hal ini dibuktikan dengan munculnya kitab Ahkāmul Qur'an karya Imam Syafi'i (w.204 $\mathrm{H})$. Demikian juga pengikut mazhab maliki menulis persoalan yang sama, misalnya Isma'il bin Ishaq al-Qadhi (w.282 H) atau sama juga dengan yang ditulis Imam al-Thahawi pengikut mazhab Hanafi. ${ }^{25}$ Pada era ini bermunculan juga kitab tentang sebab turun ayat/ asbābun nuzūl seperti yang ditulis oleh Ali bin Al Madini (w.234H). Kitab tentang ilmu qira'at juga mulai ditulis seperti kitab yang dikarang oleh Abi Ubaid bin al-Qasim bin Salam (w.224 H), Ahmad bin Zubair al-Kufi dan Ismail bin Ishaq al-Qadi (w.282 H). Begitu juga pada era ini sudah ada pembukuan kitab ilmu nasikh mansūkh yang dikarang oleh Qatadah bin Da'amah al-Sadusi (w.117 H), Ibnu Syihab al-Zuhri (w.124 H) dan Muqatil bin Sulaiman (w.105H). ${ }^{26}$

Seiring waktu karena kebutuhan terhadap tafsir yang mencakup seluruh isi al-Qur'an maka pada akhir abad ke-3 dan awal abad ke-4 Hijrah (ke-10 M) muncul tafsir yang mengkaji keseluruhan isi alQur'an dan membuat model paling maju dari tafsir taḥlìlì seperti tafsir yang ditulis oleh Ibnu Majah, al-Thabari. ${ }^{27}$

23 Musy'an Abdu Su'ud al-'Isawi, Tafsìr Tahlīli Tãrikh wa Tathawur, h.66.

24 Musy'an Abdu Su'ud al-'Isawi, Tafsīr Tahlīli Tärikh wa Tathawur, h.66.

25 Musy'an Abdu Su'ud al-'Isawi, Tafsīr Tahlīli Tārikh wa Tathawur, h.66.

26 Musy'an Abdu Su'ud al-'Isawi, Tafsīr Tahlīli Tārikh wa Tathawur, h.67.

27 M. Quraish Shihab dkk, Sejarah dan 'Ulum al-Qur'an, (Jakarta: Pustaka Firdaus, 2008), h. 174.

HIKMAH, Vol. XV, No. 2, $2019 \sim 189$ 
Metode tafsir taḥlīì merupakan metode penafsiran al-Qur'an yang digunakan oleh para mufassir klasik dan terus berkembang hingga kini. Dalam perkembangannya kitab-kitab tafsir yang menggunakan metode ini ada yang ditulis dengan sangat panjang seperti karya Ibnu Jarir al-Thabari, Fakhr al-Din al-Razi dan tafsir karya al-Alusi. Sementara di antara karya tafsir dengan mentode tahlīlī yang ditulis dengan penjelasan sedang adalah seperti tafsir karya al-Naisaburi dan Iman al-Baidhawi. Adapun contoh karya tafsir yang menggunakan metode ini dengan penjelasan yang ringkas namun jelas dan padat adalah kitab tafsir karya Jalal al-din Suyuthi. ${ }^{28}$

\section{TAFSIR TAHLILI: KELEBIHAN DAN KEKURANGAN}

Metode tahlīlì sebagai salah satu metode tafsir yang popular memiliki keunggulan dibandingkan dengan metode tafsir lainnya, diantaranya ruang lingkup bahasan yang sangat luas disebabkan memiliki dua bentuk tafsir yaitu tafsir ma'tsur dan ra'yu yang dapat memunculkan beraneka ragam corak disiplin dan menjadi wadah berbagai gagasan. ${ }^{29}$ Menurut Hasan Hanafi metode ini memiliki kelebihan dalam memberikan informasi yang maksimal terkait lingkungan sosial, linguistik dan sejarah dari teks. Komentar klasik para sejarawan memberitakan informasi setting masa lalu dari teks sementara komentar modern dari pembaharu menunjukkan setting sosial politik modern. Di sini tujuan para modernis tidak hanya memahami makna teks melainkan juga merubah realitas. Penafsiran dengan metode ini membantu pembaca untuk memahami mentalitas para mufassir klasik, sumber pengetahuan, situasi historis dan tingkat pemahaman mereka. Penafsiran ini juga

28 M. Quraish Shihab dkk, Sejarah dan 'Ulum al-Qur'an, h. 172-173.

29 Ahmad Syukri Saleh, Metodologi Tafsir al-Qur'an, h. 51. Metode tahlili memiliki beragam urgensi di antaranya: Metode ini meneliti setiap bagian nash al-Qur'an secara detail tanpa meninggalkan sesuatupun, Menyeru peneliti dan pembaca untuk mendalami ilmu ilmu qur'an yang beragam, metode ini memperdalam pemikiran dan menambah kuat dalam menyelami makna ayat serta tidak puas hanya melihat makna global saja, tafsir tahlili menjadi pengantar atau asas untuk tafsir maudhu'i. Lihat Saeful Rokim, "Mengenal Metode tafsir tahlili”, Jurnal staialhidayah, Bogor, 2017, h. 44. 
melacak semangat zaman, kondisi seni dan periode sejarah. Hal ini menunjukkan bagaimana wahyu dikondisikan oleh sejarah dalam pemahamannya. ${ }^{30}$ Metode ini telah memberikan sumbangsih yang besar dalam mengembangkan tafsir al-Qur'an. Melalui metode ini telah melahirkan karya-karya tafsir yang besar. Maka mufassir yang menghendaki penjelasan yang luas terhadap ayat-ayat alQur'an maka mesti menggunakan metode tahlili.

Selain itu tafsir tahlīlì biasanya selalu memaparkan beberapa hadis ataupun perkataan sahabat dan para tabiin, yang berkenaan dengan pokok pembahasan pada ayat. Juga di dalamnya terdapat beberapa analisa mufassir mengenai hal-hal umum yang terjadi sesuai dengan ayat. Dengan demikian, informasi wawasan yang diberikan dalam tafsir ini sangat banyak dan dalam. Tafsir dengan metode ini juga memperkaya arti kata-kata dengan usaha penafsiran terhadap kosa-kata ayat. luasnya sumber tafsir metode tahlīili tersebut. Penafsiran kata dengan metode tahlīlì akan erat kaitannya dengan kaidah-kaidah bahasa Arab dan tidak tertutup kemungkinan bahwa kosa-kata ayat tersebut sedikit banyakanya bisa dijelaskan dengan kembali kepada arti kata tersebut seperti pemakaian aslinya. Pembuktian seperti ini akan banyak berkaitan dengan syair-syair kuno.

Seperti halnya metode tafsir lainnya, metode tafsir taḥlīi juga memiliki kekurangan. Menurut M.Qurais Shihab ada beberapa kelemahan dari metode tafsir tahlīlì di antaranya bahwa penjelasan dalam beberapa kitab-kitab tafsir taḥlìì terkesan bertele-tele karena semua yang ada dalam benak mufassir ingin dijelaskan sehingga menyebabkan kejenuhan pembaca padahal penjelasan yang disajikan tidak pernah tuntas karena terfokus pada ayat yang dibahas tanpa mengaitkannya dengan ayat lain yang memiliki keterikatan. Selanjutnya penjelasan para mufassirnya yang sangat teoritis sehingga terkesan bahwa itulah pesan al-Qur'an yang mesti diperhatikan, akibatnya membelenggu generasi yang lahir setelahnya. Kemudian Kurangnya aturan-aturan metodologis yang mesti diikuti oleh mufassir dalam menarik dan menjelaskan makna

30 Hasan Hanaf, Islam in the Modern world: vol.1 Religion, Ideologi and Development, (Heliopolis: Dar Kebaa Bookshop, 2000), h. 510. 
dan kandungan ayat-ayat al-Qur'an menjadi kelemahan utama dari metode ini. ${ }^{31}$

Selain itu metode tafsir ini membuat petunjuk al-Qur'an bersifat parsial sehingga menimbulkan kesan petunjuk yang disajikan alQur'an tidak utuh dan tidak konsisten karena penafsiran yang diberikan pada sebuah ayat berbeda dengan penjelasan pada ayat lain yang serupa. Penyebab timbulnya perbedaan karena kurang perhatian pada ayat-ayat yang serupa. Misalnya pada potongan ayat Ibnu Katsir menafsirkan dengan Adam a.s. Maka ketika ia menafsirkan ayat selanjutnya وخلق منها زوجها ia menjelaskan yaitu siti hawa diciptakan dari tulang rusuk yang sebelah kiri. Maka jelaslah نفس واحد dimaksudkan oleh Ibn Katsir dengan Adam a.s. Meskipun sekilas dalam penafsiran Ibnu Katsir tidak ada persoalan namun apabila dibandingkan dengan penafsirannya terhadap kata yang sama pada ayat lain maka akan dijumpai perbedaan seperti kata انفسكم pada ayat 128 surat at-Taubah ditafsirkan dengan “jenis"/ bangsa. Maka terlihat Ibnu Katsir tidak konsisten karena kata نفس itu keduanya secara etimologis berasal dari akar kata yang sama, sehingga membentuk نفس نفس. Perbedaan hanya terletak pada bentuk kata نفس bentuk mufrad/tunggal dan kata انفس dalam bentuk jamak. Jika dilihat pemakaian kata tersebut نفس واحد dalam al-Qur'an dalam berbagai ayat maka penafsiran dengan Adam kurang tepat karena kata Adam tidak berkonotasi jenis atau bangsa melainkan menunjuk kepada seorang individu. Dalam penafsiran Ibnu Katsir terpecah dan tidak konsisten padahal bukan al-Qur'an yang tidak konsisten tapi penafsirannya, hal tersebut disebabkan mufassir kurang memperhatikan ayat-ayat yang mirip. ${ }^{32}$

Penggunaan metode taḥlīi juga menyebabkan penafsiran yang subjektif karena fanatisme pada aliran tertentu, sikap subjektifitas dari mufassir dalam metode analisis lebih besar terjadi dibandingkan dengan tiga metode tafsir lainnya. Misalnya dalam penafsiran Ibnu Katsir terhadap ayat وخلق منها زوجها langsung

31 M. Quraish Shihab, Kaidah Tafsir, h. 379.

32 Nasharuddin Baidan, Metodologi Penafsiran al-Qur'an, h. 56. 
dikatakannya siti hawa diciptakannya dari tulang rusuk Adam yang kiri. Penjelasannya itu didasarkan pada sebuah hadis shohih yang menyatakan bahwa wanita diciptaan dari tulang rusuk yang kiri. Hal tersebut tidak heran karena ia adalah seorang ahli hadis maka ia menafsirkan al-Qur'an melalui riwayat. Namun dalam hadis tersebut tidak ditegaskan siti hawa diciptakan dari tulang rusuk nabi Adam karena teks hadis berbunyi من ضلع dari tulang rusuk secara umum namun tidak menyebut nama Adam. Munculnya kata Adam dari dalam pikiran Ibn Katsir sendiri karena secara subjektifitas dalam menafsirkan kata نفس واحد dalam kalimat sebelumnya dengan Adam. ${ }^{33}$ Jadi metode taḥlīì memberikan ruang kepada para mufassir untuk menuangkan gagasan dan pemikirannya. Seringkali para mufassir tidak menyadari melakukan penafsiran yang subjektifitas dengan tidak mengindahkan kaedah-kaedah yang berlaku. ${ }^{34}$

Selain itu dengan menggunakan metode taḥlìlì dalam menafsirkan ayat al-Qur'an masuknya pemikiran isra'iliyat pun tidak dapat dihindari. ${ }^{35}$ Terkait dengan Israiliyat yang mungkin terkadang masuk dalam informasi yang diberikan mufassir. Juga sama halnya dengan berbagai hadis lemah yang tidak selayaknya digunakan pada tempat dan kondisi sesuai. Akan tetapi dengan analisa kritis yang mendalam, kelemahan ini sangat mungkin untuk dihindarkan. Selayaknyalah memang seorang mufassir yang berkompeten untuk memberikan perhatian serius terhadap sumber informasi yang ia gunakan dalam menafsirkan sebuah ayat. Israiliyyat tidaklah begitu sulit untuk dikenali, konsepnya hanyalah apakah informasi tersebut mempunyai sumber yang jelas atau tidak, bila sumbernya jelas dan kuat maka informasi tersebut bisa dipakai dan sebaliknya. Begitu juga dengan hadis-hadis dha'if ataupun pendapat-pedapat para sahabat maupun tabi'in. Hukum dasar hadis da'if adalah tidak boleh diamalkan, hal ini tentu saja berlaku dalam pemakaian sebagai sumber tafsir. Hadist dha'if

33 Nasharuddin Baidan, Metodologi Penafsiran al-Qur'an, h. 58.

34 Hujair A.H Sanaky, "Metode Tafsir(Perkembangan Metode Tafsirmengikuti warna atau corak mufassirin”, Al-mawarid,vol.18, 2018, h. 277.

35 Nasharuddin Baidan, Metodologi Penafsiran al-Qur'an, h. 53-60. 
tersebut hanya bisa dipakai sebagai penguat apabila ada hadis yang lebih kuat menjelaskan senada dengan hadis da'if tersebut. Misalnya penafsiran al-Qurtubi tentang penciptaan manusia pertama yang terdapat dalam al-Qur'an surat al-Baqarah ayat 30 yang berbunyi جإع yang artinya Allah menciptakan Adam dengan tanganNya sendiri langsung dari tanah selama 40 tahun. Setelah kerangka itu siap lewatlah para malaikat di depannya. Mereka terperanjat karena amat kagum melihat indahnya ciptaan Allah itu dan yang paling kagum adalah iblis lalu dipukul-pukulnya kerangka Adam tersebut lantas terdengar bunyi seperti periuk belanga dipukul; seraya ia berucap" لأمر ماخلفت. Jika dicermati penafsiran al-Qurthubi terhadap ayat tersebut tidak didukung oleh argument yang kuat karena proses penciptaan adam selama 40 tahun seperti yang dikemukakan oleh al-Qurthubi tidak diketahui rujukannya baik dalam al-Qur'an maupun hadis. Penjelasan yang dikemukan oleh al-Qurthubi terhadap ayat tersebut sulit untuk diterima karena penjelasan demikian seolah menyerupakan perbuatan tuhan dengan perbuatan makhlukNya. Hal tersebut menyebabkan pemahaman terhadap petunjuk al-Qur'an menjadi bertentangan. ${ }^{36}$

Metode tafsir tahlīlì mendapatkan kritik dari Malik bin Nabi yang mengatakan bahwa tujuan utama para ulama menggunakan metode ini adalah untuk meletakkan dasar-dasar rasional bagi pemahaman dan pembuktian kemukjizatan al-Qur'an. Kritik ini bisa diterima kalau yang dimaksud adalah pada tahap awal dari lahirnya metode ini, karena dalam kenyataannya hal tersebut tidak ditemukan kecuali pada tafsir tahlili yang bercorak kebahasaan. Ditinjau dari konteks kebahasaan ini, disamping kelebihannya yang menonjol yakni pemahaman kosakata, tidak jarang juga ditemukan sang mufassir member makna yang berlebih atau berkurang dari apa yang seharusnya ditampung oleh kata yang ditafsirkannya. Kitab tafsir yang menekankan uraiannya pada hukum/fiqh banyak yang dikritik karena penulisannya terlalu menekankan pada pandangan mazhabnya. ${ }^{37}$

36 Nasharuddin Baidan, Metodologi Penafsiran al-Qur'an, h. 60-61

37 M. Quraish Shihab, Kaidah Tafsir, h. 379. 


\section{RAGAM METODE TAFSIR TAHLILI}

Secara tehnis dalam menggunakan metode ini, para mufassir tidak seragam ada yang menguraikannya secara ringkas dan sebaliknya ada yang menguraikannya secara terperinci. Menurut Abdul Hayy al-Farmawi ada beberapa ragam tafsir tahlili di antaranya, tafsir bi al-Ma'tsur, tafsir bi al-Ra'yi, tafsir ash Shufi, tafsir al Fiqhi, tafsir al Falsafi, tafsir al 'ilmi dan tafsir al Adabi Al Ijtima. ${ }^{38}$

\section{Tafsīr bi al-Ma'tsur (riwayat)}

Secara bahasa tafsir bil ma'tsur yaitu penafsiran yang menjadikan riwayat sebagai sumber penafsiran sehingga tafsir bil ma'tsur dikenal juga dengan sebutan tafsir bil riwayah/tafsir dengan periwayatan atau dengan sebutan lain tafsir bi al manqul/ tafsir dengan menggunakan pengutipan. Jadi, Tafsir bil ma'tsur merupakan suatu bentuk penafsiran yang berdasarkan ayat al-Qur'an, hadis nabi, pendapat sahabat atau tabi'in. Pertama, penafsiran ayat al-Qur'an dengan ayat lain. Para ahli tafsir berpendapat bahwa ayat-ayat al-Qur'an saling menafsirkan satu ayat dengan ayat yang lain. Di antaranya ada ayat atau ayat-ayat lain menjabarkan apa yang diungkapkan pada ayat-ayat tertentu. Seperti dalam surat al-Baqarah ayat 1 terdapat kata al-Muttaqin yang kemudian dijabarkan oleh ayat yang berada sesudahnya pada ayat 3-5 yang berbunyi:

$$
\begin{aligned}
& \text { الذين يؤمنون بالغبيب ويقيمون الصلاة ومما رزقناهم ينفقون والذين }
\end{aligned}
$$

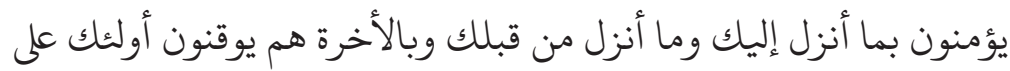

$$
\begin{aligned}
& \text { هدى من ربهم وأوليك هم المفلحون }
\end{aligned}
$$

Yaitu orang-orang yang beriman kepada yang ghaib, mendirikan sholat dan menafkahkan sebagian rezki yang kami berikan kepada mereka dan mereka yang beriman kepada kitab (al-Qur'an) yang telah diturunkan sebelummu serta mereka yakin akan adanya (kehidupan) akhirat. Mereka itulah yang tetap mendapat petunjuk

38 Abd Hayy al-Farmawi, al-Bidayah fi al-Tafsir al-Maudhu'i, h. 24 
dari Tuhannya dan mereka orang-orang yang beruntung.

Selanjutnya ada juga ayat-ayat yang panjang lebar menjelaskan ayat-ayat yang mengandung informasi yang lebih ringkas, seperti kisah nabi Musa pada satu surah di jelaskan secara ringkas sementara di surah yang lain diungkapkan lebih rinci. Kemudian ayat-ayat yang mengandung pengertian global dijelaskan ayat-ayat yang mengandung pengertian khusus. Jadi ada ayat-ayat yang 'am ditafsirkan oleh ayat-ayat yang khas. Ayat-ayat yang mujmal dijelaskan oleh ayat-ayat yang mubayyan. Begitu pula informasi yang terdapat dalam satu ayat kadang kala terlihat tidak sama dengan ayat yang terdapat pada ayat lain. Penafsiran ayat-ayat itu dikompromikan pengertianpengertian tersebut.

Kedua, Penafsiran ayat al-Qur'an dengan hadis nabi saw. Hadis nabi dijadikan para mufassir sebagai bahan yang penting dalam menjelaskan ayat-ayat al-Qur'an karena setelah alQur'an otoritas dalam menafsirkan al-Qur'an berada di tangan nabi Muhammad Saw. Ketiga, Penafsiran ayat al-Qur'an dengan pendapat para sahabat. Generasi sahabat merupakan orang yang paling memahami al-Qur'an setelah Nabi Saw. wafat karena mereka hidup pada saat al-Qur'an masih diturunkan. Mereka mendapat penjelasan langsung dari nabi yang paling paham dengan petunjuk al-Qur'an serta serta terlibat langsung dengan situasi dan kondisi saat al-Qur'an turun. Maka tidak heran jika pendapat-pendapat para sahabat dijadikan bahan penting oleh para mufassir dalam menjelaskan ayat-ayat al-Qur'an. Keempat, Penafsiran al-Qur'an dengan pendapat para tabi'in. Generasi tabi'in dianggap sebagai orang yang paling paham penjelasan al-Qur'an setelah generasi para sahabat karena mereka belajar dengan para sahabat. Oleh sebab itu maka pendapat-pendapat generasi thabi'in dianggap membantu generasi selanjutnya dalam memahami petunjuk al-Qur'an. ${ }^{39}$

Dalam sejarah munculnya tafsir bil ma'tsur dapat dibagi menjadi dua tahap yaitu periode Riwayah dan periode Tadwin.

39 M. Quraish Shihab dkk, Sejarah dan 'Ulum al-Qur'an, h. 176. 
Pertama, Periode Riwayah yaitu masa Rasulullah s.a.w., para shahabat dan tabi'in. Rasul menjelaskan apa yang terkandung dalam makna al-Qur'an kepada para shahabat. Para shahabat adakalanya meriwayatkan kepada yang lain dan kemudian meriwayatkan kepada tabi'in. Oleh karena itu, periode ini disebut juga dengan periode Syafahiyah yaitu pengajaran secara langsung. Kedua, Era Tadwin (pembukuan). Pada periode ini dilakukan pencatatan dan pembukuan segala yang diriwayatkan dari Rasulullah s.a.w. dan para shahabat. Jadi, pembukuan telah dimulai pada masa shahabat, tetapi penyusunannya secara sistematis sebagai ilmu yang mandiri dan terpisah dari hadis secara sempurna baru terjadi pada abad ketiga hijriyah.

Metode tahlili dengan pendekatan tafsir bi al-matstur memiliki kelebihan, diantaranya: Menekankan pentingnya bahasa dalam memahami al-Quran, Memaparkan ketelitian redaksi ayat ketika meyampaikan pesan-pesannya, Megikat mufasir dalam bingkai teks ayat-ayat, sehingga membatasinya terjerumus dalam subjektifitas berlebihan. Namun tafsir bil ma'tsur sangat rentan terhadap masuknya pendapat-pendapat di luar Islam, seperti kaum zindiq Yahudi, Parsi, dan Parsi, dan masuknya hadits-hadits yang tidak shahih. ${ }^{40}$ Selain itu, terjerumusnya sang mufasir dalam uraian kebahasaan dan kesustrasaan yang bertele-tele sehingga pesan pokok al-Quran menjadi kabur dicelah uraian itu, Seringkali konteks turunnya ayat (uraian asbab nuzulatau situasi kronologis turunnya ayat-ayat hukum yang dipahami dari uraian nasikh mansukh) hampir dapat dikatakan terabaikan sama sekali, sehingga ayat tersebutbagaikan turun bukan dalam satu masa atau berada ditengah-tengah masyarakat tanpa budaya. ${ }^{41}$

\section{Tafsīr bi al-Ra'yi}

Tafsir bil ra'y merupakan bentuk penafsiran yang bedasarkan hasil nalar (ijtihad) mufassir sendiri sehingga corak penafsiran mendapat ruang gerak yang luas seperti corak

40 Nur Kholis, Pengantar Al-Qur'an dan Hadis, (Yogyakarta: Sukses offset, 2008), h.144

41 Quraish Shihab, Membumikan al-Qur'an: Fungsi dan Peran Wahyu dalam kehidupan Masyarakat, (Bandung: Mizan, 1992), h.84 
filsafat, teologi, hukum, sastra, bahasa dan ilmu pengetahuan. ${ }^{42}$ Ditinjau dari penekanan penyajian penafsirannya meliputi beragam corak disiplin ilmu seperti hukum, tasawuf, filsafat, ilmu pengetahuan, bahasa dan sosial budaya. Corak penafsiran yang beragam berguna dalam memberikan informasi yang rinci pada pembaca terkait situasi yang dialami, kecendrungan dan keahlian setiap pakar tafsir. ${ }^{43}$

Tafsir bi al-Ra'yi merupakan penafsiran yang menjadikan rasio atau hasil pemikiran seorang mufassir sebagai titik tolak sehingga perbedaan antara para mufassir sulit dihindari dibandingkan dengan tafsir bi al-ma'tsur. Oleh sebab itu beberapa ulama tidak menerima penafsiran dengan corak ini serta menamainya dengan istilah al-tafsir bi al hawa, tafsir berdasarkan hawa nafsu. Namun sebagian besar ulama yang menerima tafsir dengan corak ini namun dengan syarat-syarat tertentu.

Beberapa ayat yang menjadi dalil dibolehkannya tafsir bil ra'y di antaranya sebagai berikut:

$$
\text { أفلا يتدبرون القرآن آم على قلوب أقفالها }
$$

Apakah mereka tidak memperhatikan al-Qur'an ataukah hati mereka terkunci? (Q.S. Muhammad/47:24)

$$
\text { كتاب أنزلناه إليك مبارك ليدبروا ايته وليتذكر أولوا الألباب }
$$

Ini adalah kitab yang Kami turunkan kepadamu, penuh dengan berkah agar mereka memperhatikan ayat-ayat dan orang-orang yang mempunyai pikiran dapat memperoleh pelajaran darinya (Q.S. Shad/38:29)

Di antara syarat-syarat yang diberlakukan pada para mufassir dalam menggunakan bentuk tafsir ini adalah memiliki pengetahuan tentang bahasa Arab dan segala seluk beluknya, menguasai ilmu-ilmu al-Qur'an, menguasai ilmu-ilmu yang

42 Lihat Ahmad Syukri Saleh, Metodologi Tafsir al-Qur'an, h. 50.

43 Nasharuddin Baidan, Metodologi Penafsiran al-Qur'an, h. 6-7. 
berhubungan dengan ilmu-ilmu al-Qur'an misalnya ushul fiqh dan hadis, berakidah yang benar. Mengetahui prinsip-prinsip pokok agama Islam, menguasai ilmu yang berhubungan dengan pokok bahasan ayat yang ditafsirkan. ${ }^{44}$ Selain itu para mufassir mempunyai iktikad yang lurus dan benar serta selalu menepati ketentuan agama, ikhlas, berpedoman pada riwayat yang maqbul dan menjauhi bid'ah. ${ }^{45}$ Sementara itu Ali Hasan al-Arid mengemukakan ada enam hal yang mesti dihindari para mufassir yang hendak menggunakan tafsir dengan bentuk bil ra'y yaitu memaksakan diri mengetahui makna yang dikehendaki Allah pada suatu ayat sementara ia sendiri tidak memenuhi syarat untuk itu, mencoba menafsirkan ayat-ayat yang maknanya hanya diketahui oleh Allah swt, mena fsirkan ayat-ayat al-Qur'an karena dorongan hawa nafsu dan sikap istihsān (penetapan hukum suatu perkara tidak berdasarkan alasan hukum yang tepat menurut nash), menafsirkan ayatayat menurut makna yang tidak terkandung di dalamnya, menafsirkan ayat untuk mendukung mazhab atau aliran sesat tertentu dengan cara menjadikan paham aliran atau mazhab tersebut, menafsirkan ayat-ayat disertai kepastian bahwa makna itulah yang dikehendaki Allah tanpa dukungan dalildalil atau memutlakan pendapatnya sendiri dan menyalahkan pendapat yang lain. ${ }^{46}$

Berikut contoh tafsìr bil ra'y yaitu, dari penjelasan Q.S. Al-Baqarah: 115, yaitu sesuai dengan maksud ayat surat alBaqarah ayat 150 berikut:

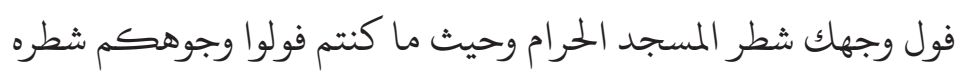
"niscaya (di sana ada Allah), artinya di tepat itu ada Allah, yaitu tempat yang disenangi-Nya dan diperintahkan-Nya (kamu) untuk menghadap-Nya di situ".

44 M. Quraish Shihab dkk, Sejarah dan 'Ulum al-Qur'an, h. 178.

45 Malik Ibrahim, Corak dan Pendekatan Tafsir al-Qur'an, Sosio Religia, Vol 9, Nomor 3 Mei 2010, h. 645.

46 Ali Hasan al-Arid, Tärikh 'ilm al-Tafsir wa Manāhij al-Mufassirīn, terjemahan Ahmad Akrom, Sejarah dan Metodologi Tafsir (Jakarta: Rajawali Press, 1992), h.10. 
Yang dimaksud ialah apabila kamu terhalang melakukan shalat di Masjidil Haram dan Baitul Maqdis, maka janganlah khawatir sebab permukaan bumi telah Ku-jadikan masjid tempat sembahyang bagimu. Dari itu, kamu boleh sembahyang di tempat mana saja di muka bumi ini, dan silakan menghadap ke arah mana saja yang dapat kamu lakukan ditempat itu, tidak terikat pada masjid tertentu dan tidak pula yang lain, demikian pula tidak terikat lokasi mana pun. Hal itu dimungkinkan karena Allah Maha Lapang dan Maha Luas. Dia ingin memberi kelonggaran dan kemudahan kepada hamba-hamba-Nya (lagi Maha Mengetahui) tentang kemashlahatan dan kebutuhan mereka. Latar belakang ini berdasarkan dengan latar belakang turunnya ayat yang berkenaan dengan shalatnya seorang musafir di atas kendaraan di mana dia menghadap arah kendaraannya.

\section{Tafsir Shufi}

Corak Tafsir Shufi mulai muncul saat ilmu-ilmu agama dan ilmu pengetahuan mengalami kemajuan pesat sertakebudayaan Islam tersebar di penjuru dunia dan mengalami kemajuan dalam berbagai aspeknya. Tafsir dengan corak ini lebih fokus pada aspek dan dari sudut esoterik atau isyarat-isyarat yang tersirat dari ayat oleh para tasawuf. Metode dengan corak ini dibagi menjadi dua yaitu, teoritis dan praktis. Pada bentuk teoritis, mufasir menafsirkan Al-Qur'an dengan menggunakan mazhabnya dan sesuai dengan ajaran-ajaran mereka. Mereka menta'wilkan ayat-ayat Al-Qur'an dengan penjelasan yang menyimpang dari pengertian tekstual yang telah dikenal dan didukung oleh dalili Syar'i. Sementara dalam bentuk praktis, mufasir menafsirkan ayat-ayat Al-Qur'an dengan berdasarkan isyarat-isyarat tersembunyi. Oleh para ulama tafsir yang sejalan dengan al-Tasawuf al Nazhari dinamakan al-Tasawuf al Shufi al Nazhari, sementara tafsir yang sesuai dengan al-Tasawuf al'Amali disebut dengan al-Tafsir al-'Isyari. ${ }^{47}$

Berikut contoh penafsiran dalam tafsir shufi:

47 M. Quraish Shihab dkk, Sejarah dan 'Ulum al-Qur'an, h. 180. 
"dan Kami mengangkatnya ke tempat paling tinggi". (Q.S.Maryam: 57). Ia berkata, "tempat paling tinggi adalah tempat yang diputari rotasi alam raya, yaitu orbit matahari. Disitulah maqam (tempat tinggal) rohani Idris....". kemudian Ia berkata lebih lanjut: "adapun kedudukan (bukan tempat) paling tinggi adalah tempat untuk kita, umat Muhammad, sebagaimana telh dijelaskan-Nya,kalian adalah orang-orang yang paling tinggi dan Allah (pun) senantiasa bersama kalian (Q.S.Muhammad: 35). Jadi yang maksudkan (berkenaan dengan Idris) ini adalah ketinggian tempat, bukan ketinggian kedudukan. ${ }^{48}$

Tafsir dengan corak ini dapat diterima dengan beberapa syarat, di antaranya, Tidak meninggalkan makna lahir atau pengetahuan tekstual al-Qur'an, Penafsiran diperkuat oleh dalil syara' yang lain, Penafsiran tidak bertentangan dengan syara', Mengakui pengertian tekstual terlebih dahulu. ${ }^{49}$

\section{Tafsir Fikih}

Corak Tafsir Fikih adalah tafsir yang lebih cendrung pada tinjauan hukum dari ayat yang di tafsirkan. Tafsir ini banyak di temukan dalam kitab-kitab fikih yang dikarang oleh imamimam dari berbagai mazhab yang berbeda. Tafsir ini muncul seiring dengan kemunculan tafsir bil ma'tsur. Hal tersebut karena dalam pembinaan masyarakat Islam di Madinah nabi banyak sekali mendapat pertanyaan dari para sahabat terkait dengan pertanyaan hukum. Kemudian jawaban-jawaban nabi tersebut secara lisan diriwayatkan dari satu generasi ke generasi selanjutnya. Para sahabat setelah Rasulullah wafat banyak melakukan ijtihad dalam menetapkan hukum-hukum terkait dengan persoalan-persoalan yang belum ada pada masa Rasulullah dan tidak ditemukan hadis yang membahas persoalan tersebut. ${ }^{50}$

48 Manna Khil al-Qattan, Studi Ilmu-ilmu Al-Qur'an, h.24.

49 Roshian Anwar, Ilmu Tafsir, (Bandung: Pustaka Setia, 2005), h. 167.

50 M. Quraish Shihab dkk, Sejarah dan 'Ulum al-Qur'an, h. 179. 


\section{Tafsir Falsafi}

Tafsir Falsafi merupakan ilmu tafsir yang menafsirkan AlQur'an dengan menggunakan pendekatan filsafat. Pendekat filsafat yang digunakan adalah pendekatan yang berusaha melakukan sintesis dan siskretisasi antara teori-teori filsafat dengan ayat-ayat Al-Qur'an, selain itu juga menggunakan pendekatan yang berusaha menolak teori-teori filsafat yang dianggap bertentangan dengan ayat-ayat Al-Qur'an. Di antara ulama yang membela pemikiran filsafat adalah Ibn Rusyd seorang filosof terkenal yang berasal dari spanyol Islam dengan menulis buku dengan judul Tahafut al Tahafut yang berisi sanggahan terhadap karya Imam al-Ghazali yaitu Tahafut al Falāsifah. Sementara ulama yang dianggap menolak pemikiran filsafat di antaranya Imam al-Ghazali dan Fakh al Din al-Razi dengan kitab tafsirnya Mafātih al-Ghaib. ${ }^{51}$

\section{Tafsir 'Ilmi}

Tafsir ini mulai muncul akibat dari perkembangan ilmu pengetahuan yang sangat pesat, sehingga tafsir ini dalam menafsirkan Al-Qur'an dengan menggunakan pendekatan almiahataudengan menggunakan teori-teoriilmupengetahuan. Dalam tafsir ini mufasir berusaha mengkaji Al-Qur'an dengan dikaitkan dengan gejala atau fenomena-fenomena yang terjadi di alam semesta ini. Namun, yang sangat disayangkan adalah pada tafsir ini terbatas pada ayat-ayat tertentu dan bersifat parsial, terpisah dengan ayat-ayat lain yang berbicara pada masalah yang sama. Dalam perkembangannya saat ini tafsir 'ilmi menjadi tafsir maudhū'I karena ayat-ayat al-Qur'an dipilah pilah dalam disiplin ilmu lalu ditafsirkan merujuk pada teoriteori ilmiah. ${ }^{52}$

\section{Tafsir Adab Al-Ijtima'i}

Tafsir Adabi Al-Ijtima'i adalah suatu metode tafsir yang coraknya menjelaskan petunjuk-petunjuk ayat Al-Qur'an yang

51 M. Quraish Shihab dkk, Sejarah dan 'Ulum al-Qur'an, h. 183.

52 M. Quraish Shihab dkk, Sejarah dan 'Ulum al-Qur'an, h. 183. 
berkaitan langsung dengan kehidupan kemasyarakatan, serta usaha-usaha untuk menanggulangi penyakit-penyakit atau masalah-masalah kemasyarakatan berdasarkan petunjuk AlQur'an dengan mengemukakannya menggunakan bahasa yang mudah dimengerti dan indah didengar. Para mufassir dalam corak tafsir ini tidak membahas secara rinci penjelasan pengertian bahasa yang rumit namun menurut mereka yang penting adalah menyampaikan misi al-Quran terhadap pembaca. Corak tafsir ini baru muncul pada masa modern. ${ }^{53}$

Para mufassir ada yang menyajikan penjelasan terhadap ayat-ayat secara terperinci dengan menggunakan Tafsir tahlīili bil ma'tsur. Di antara kitab tafsir yang masuk ke dalam kelompok al-Ma'tsur adalah tafsir karya Ibn Jarir al-Thabari (w.310 H) berjudul Tafsir al-Thabari, Tafsìr al-Qur'an al-'Azhim karya Ibnu Katsir dan al-Durr al-Mantsur fi tafsir bi al-Ma'tsur karangan al-Suyuthi (w.911 H). Sementara kitab tafsir bi alra'yu di antaranya adalah al-Jami' al Ahkām al-Qur'an karya al-Qurthubi, Kitab tafsir al-Tafsīr al-Kabìr wa Mafātih alGhayb karangan Fakhr al-din al-Razi (w. 606 H) dan al-Kasyāf 'an haqaiq al-Tanzil wa 'uyun al-aqawil fi wujuh al-ta'wīl karya Mahmud bin 'Umar al-Zamakhsyari (w. 538). Berikut contoh tafsir bil ra'y yang beorientasi pada corak disiplin tertentu seperti corak hukum Ahkām al-Qur'an karya Jashshash (w. 370), Bercorak sufi Haqaiq al-Tafsìr karya al-Sulami (w. 412), bercorak ilmu pengetahuan al-Qur'an wa 'ilmu Hadits karya 'Abd al-Razzaq Naufal (w. 1354), serta tafsir yang bercorak sastra sosial kemasyarakatan tafsìr al-Maraghi karya Ahmad Mustafa al-Maraghi (w. 1945 M). ${ }^{54}$

\section{E. LANGKAH-LANGKAH PENAFSIRAN TAHLILI DAN CONTOHNYA}

Dalam menerapkan metode ini pada umumnya mufassir menjelaskan makna yang terkandung dalam al-Qur'an, ayat demi

53 Abd Hayy al-Farmawi, al-Bidāyah fi al-Tafsìr al-Maudhü'i, h. 41.

54 Lihat Ahmad Syukri Saleh, Metodologi Tafsir al-Qur'an, h. 50. 
ayat dan surat demi surat sesuai urutan bacaan yang terdapat dalam al-Qur'an mushaf. Penyajian meliputi berbagai aspek yang dikandung ayat yang ditafsirkan seperti kosakata, latar belakang turun ayat (asbab nuzul ayat), munasabah ayat, pendapatpendapat berkenaan dengan tafsiran ayat-ayat tersebut baik yang disampaikan nabi, sahabat maupun para tabi'in. ${ }^{55}$

Para Mufassir dalam menggunakana Metode tahlili dalam menjelaskan ayat-ayat Al-Qur'an dilakukan dengan menempuh cara sebagai berikut: Pertama, Menyebutkan sejumlah ayat pada awal pembahasan Pada setiap pembahasan dimulai dengan mencantumkan satu ayat, dua ayat, atau tiga ayat Al Qur'an untuk maksud tertentu, yaitu keterangan global (ijmal) bagi surat dan menjelaskan maksudnya yang mendasar. ${ }^{56}$ Kedua, Menjelaskan arti kata-kata yang sulit. Setelah menafsirkan dan menyebutkan ayat-ayat yang akan dibahas kemudian diuraikan lafadz yang sulit bagi kebanyakan pembaca. Penafsir meneliti muatan lafadz itu kemudian menetapkan arti yang paling tepat setelah memerhatikan berbagai hal yang munasabah dengan ayat itu. Ketiga, Memberikan garis besar maksud beberapa ayat. Untuk memahami pengertian satu kata dalam rangkaian satu ayat tidak bisa dilepaskan dengan konteks kata tersebut dengan seluruh kata dalam redaksi ayat itu. Keempat, Menerangkan konteks ayat. Untuk memahami pengertian satu kata dalam rangkaian satu ayat tidak bisa dilepaskan dengan konteks kata tersebut dengan seluruh kata dalam redaksi ayat itu. Kelima, Menerangkan Sebab-sebab turun ayat. Menerangkan sebab-sebab turun ayat dengan berdasarkan riwaat sah. Dengan mengetahui sebab turun ayat akan membantu dalam memahami ayat. Hal ini dapat dimengerti karena ilmu tentang sebab akan menimbulkan ilmu tentang akibat. Keenam, Memerhatikan keterangan-keterangan yang bersumber dari nabi dan sahabat atau tabi'in. Cara menafsirkan al-Qur'an yang terbaik adalah mencari tafsirannya dari al-Qur'an, apabila tidak dijumpai di dalamnya maka mencari tafsirannya dari sunnah. Apabila sunnah

55 Nasharuddin Baidan, Metode Penafsiran al-Qur'an, h. 68-69.

56 Rohimin, Metodologi Ilmu Tafsir dan Aplikasi Model Penafsiran, (Yogyakarta: Pustaka Belajar, 2007), h. 68 . 
tidak dijumpai, maka dikembalikan kepada perkataan sahabat dan tabiin. Ketujuh, Memahami disiplin ilmu tertentu. Dinamika transformasi peradaban akan membawa pengaruh terhadap pemahaman al-Qur'an. Sudah jelas Al Qur'an sangat menghargai transformasi peradaban yang sarat dengan inovasi-inovasi ilmiah. Al-Qur'an sangat menghargai penemuan-penemuan ilmiah dengan berprinsip pada ada tidakya redaksi ayat yang dapat membenarkan penemuan itu. ${ }^{57}$

Secara umum langkah-langkah dalam metode tahlili dalam kitab-kitab tafsir meliputi tujuh langkah. Pertama, penjelasan munasābah ayat baik antara ayat satu dengan ayat yang lain maupun antara satu surah dengan surah lain. Kedua, penjelasan sebab turun ayat (jika ada). Ketiga, pengertian umum kosa kata ayat dalam al-Qur'an terkait juga dengan i'rab dan ragam qira'at. Keempat, penyajian kandungan ayat secara umum dan maksudnya. Kelima, penjelasan kandungan baläghah al-Qur'an. Keenam, penjelasan hukum fiqh yang diambil dari ayat. Ketujuh, menerangkan makna dan tujuan syara' yang terdapat dalam al-Qur'an yang disandarkan pada ayat-ayat lainnya, hadits Nabi Saw, pendapat para sahabat dan tabi'in selain ijtihad mufassir sendiri. Terutama tafsir yang bercorak al-tafsir al'ilmi (penafsiran dengan ilmu pengetahuan) atau al-Tafsir al-Adabi al-Ijtima'i umumnya mengutip pendapat para ilmuan sebelumnya, teori ilmiah dan lainnya. ${ }^{58}$ Dalam prakteknya para mufassir dalam menggunakan metode tahlili tidak sama dalam urutan langkah-langkahnya. Ada juga yang tidak menggunakan salah satu dari langkah tersebut, jadi lebih tergantung kepada hal yang dipandang penting oleh mufassir. Berikut contoh penggunaan langkah-langkah dalam metode taḥlīì pada kitab tafsir karangan al-Thabari dan Fakhrudin al-Razi dan tafsir Ibn Asyur.

57 Rohimin, Metodologi Ilmu Tafsir dan Aplikasi Model Penafsiran, h. 70.

58 M. Quraish Shihab, Sejarah dan 'Ulum al-qur'an, h. 173-174. Selanjutnya h-h yang berkembang dari langkah-langkah metode tafsir tahlili adalah menampilkan faedah dari nash ayat, hikmah persyariatan dalam ayat, I'jaz keilmuan dalam nash al-Qur'an, penjelasan historis masyarakat, kandungan pengetahuan insane dan sosial kontemporer. Lihat Saeful Rokim, Mengenal Metode tafsir tahlīli, Jurnal staialhidayah bogor, 2017, h. 53. 


\section{Tafsir karya al-Thabari (w.310 H)}

Tafsir al-Thabari merupakan tafsir pertama di antara kitabkitab tafsir dari segi zaman karena merupakan tafsir bil ma'tsur yang paling tua yang sampai ke tangan kita dan dari segi penulisan dan penyusunan karena memiliki metode tersendiri yang menarik yang menjadikannya berbobot dan berkualitas. ${ }^{59}$

Al-Thabari dalam menafsiran al-Qur'an menggunakan metode tahlīlì. Dia memulai penafsirannya dengan menyebutkan terlebih dahulu nama surah, penjelasan sebab turun ayat (jika ada), kemudian masuk kepada penafsiran ayat-ayat al-Qur'an dengan menampilkan riwayat-riwayat dari Nabi Saw, sahabat dan para tabi in dalam setiap penafsirannya. Setelah itu menjelaskan perbedaan qira'at bila ayat al-Qu'an yang dibahas mengandung perbedaan-perbedaan qira'at. Dalam menjelaskan ayat al-Qur'an bila terdapat perbedaan riwayat tentang makna kata dari suatu ayat al-Qur'an, dia menampilkan terlebih dahulu perbedaan itu kemudian melakukan tarjih terhadap pendapat yang dikutipnya. ${ }^{60}$

\section{Tafsir karya Fakhr al Razi (w. 606 H)}

Fakhruddin al-Razi dalam tafsirnya al-Tafsīr al-kabìr wa mafätih al-Ghayb menggunakan metode taḥlìì. Dalam menafsirkan ayat-ayat al-Qur'an al-Razi memulainya dengan menyebutkan munāsabah ayat. Setelah itu ia menyajikan berbagai macam qira'at dan juga sebab turun ayat jika surat tersebut memiliki asbābun nuzūl ayat. Ia juga melakukan analisis bahasa secara panjang lebar. Menyebutkan nama surat, tempat turun dan jumlah ayatnya, misalnya surat al-Zalzalah. Surat ini termasuk dalam kategori surat Madaniyah dan terdiri dari delapan ayat. Al-Razi juga seringkali menyajikan pertanyaanpertanyaan ketika menafsirkan ayat-ayat al-Qur'an. Dan pada akhir setiap penafsiran surat, al-Razi menutupnya dengan wallahu a'lam dan ucapan shalawat kepada Nabi Saw. ${ }^{61}$

59 Muhammad Husain al-Dzahabi, al-Tafsìr wa al Mufassirūn, (Kairo: Maktabah Wahbah, 19976) Juz I/100.

60 Faizah Ali Syibromalisi dan Jauhar Azizy, Membahas Kitab Tafsir Klasik-Modern, (Jakarta: Lembaga Penelitian UIN Syarif Hidayatullah Jakarta, 2011), h. 17.

61 Faizah Ali Syibromalisi dan Jauhar Azizy, Membahas Kitab Tafsir, h. 59-61. 


\section{Tafsir Ibn Asyur (w.1393 H)}

Dalam menafsirkan ayat-ayat al-Qur'an, Ibn Asyur menggunakan metode tahlīì. Dalam menyajikan penafsiran dalam kitab tafsirnya, ia terlebih dahulu menjelaskan nama surah dan nama-nama lainnya jika ada, menjelaskan keutamaannya, menjelaskan Makkiah atau Madaniyah ayat dan jumlah ayat. Menjelaskan kandungan surah secara global dalam poin-poin yang berbeda-beda sesuai dengan masalah dan tema yang dibahas dan sesuai dengan susunannya dalam alQur'an. Menjelaskan kandungan ayat demi ayat atau beberapa ayat yang memiliki masalah atau tema yang sama secara rinci. Dimulai dari pemaknaan kosakata dengan i'rab dan pemaparan ¡jaz lughawi-nya terkadang menjadikan syair-syair Arab jahili sebagai syawāhid atau penguat kebahasaannya. Ibnu Asyur juga memberikan penjelasan tentang munāsabah ayat, sebab turun ayat, naskh dan mansukh dan lain-lain.

\section{F. CONTOH METODE TAFSIR TAHLILI AL-THABARI}

Untuk menggambarkan penafsiran ayat al-Qur'an yang menggunakan metode tafsir tahlīilì, berikut kutipan penafsiran potongan ayat 34 dalam surat an-Nisa' [4] yang ditafsirkan oleh alThabari dalam karyanya Jami' al-Bayān fi Tafsìr al-Qur'an al-Karìm jilid 1.

$$
\text { القول في تأويل قوله تعالى: - مالى }
$$

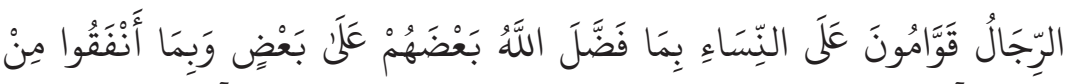

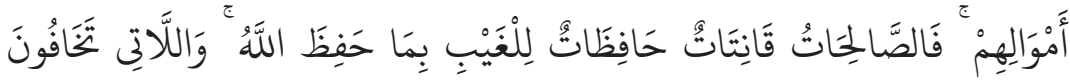

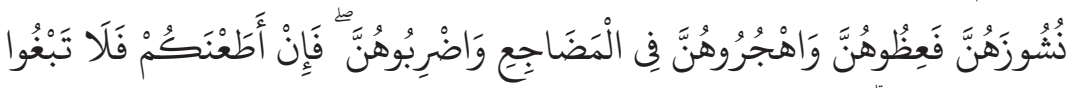

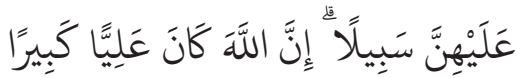

Kaum laki-laki itu adalah pemimpin bagi kaum wanita, oleh karena Allah telah melebihkan sebahagian mereka (laki-laki) atas sebahagian yang lain (wanita), dan karena mereka (laki-laki) telah 
menafkahkan sebagian dari harta mereka. Sebab itu maka wanita yang saleh, ialah yang taat kepada Allah lagi memelihara diri ketika suaminya tidak ada, oleh karena Allah telah memelihara (mereka). Wanita-wanita yang kamu khawatirkan nusyuznya, maka nasehatilah mereka dan pisahkanlah mereka di tempat tidur mereka, dan pukullah mereka. Kemudian jika mereka mentaatimu, maka janganlah kamu mencari-cari jalan untuk menyusahkannya. Sesungguhnya Allah Maha Tinggi lagi Maha Besar. ${ }^{62}$

kaum laki-laki itu adalah pemimpin bagi kaum wanita" adalah kaum laki-laki merupakan orang yang bertugas mendidik dan istri-istri mereka dalam melaksanakan kewajiban terhadap Allah dan suami (بَمَا فَضَّلَ اللَّهُ بَعْضَهُم عَلَّ بَعْضِ), yakni kelebihan yang Allah berikan kepada kaumlaki-lakiatas istri-istrinya itu disebabkan pemberian mahar, pemberian nafkah dari hartanya dan merekalah yang mencukupi kebutuhan isti-istri mereka. Itu merupakan keutamaan yang Allah berikan kepada kaum laki-laki atas istri-istri mereka. Oleh karena itu mereka menjadi pemimpin atas istri-istri mereka sekaligus orang yang melaksanakan apa yang Allah wajibkan kepada mereka dalam urusan istri-istri mereka. Kemudian al-Thabari menyebutkan beberapa riwayat yang sesuai dengan pendapat tersebut, di antaranya:

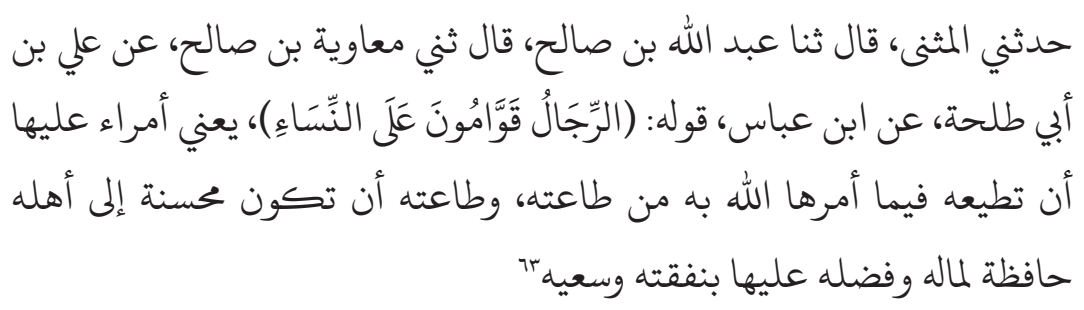

Disebutkan bahwa ayat ini diturunkan berkenaan dengan seorang suami yang menampar istrinya, kemudian dia dilaporkan kepada Rasulullah Saw tentang perbuatannya itu, dan Rasulullah memutuskan qishash untuknya. ${ }^{64}$ Lalu al- Thabari menyebutkan

62 Surat an-Nisa' (4) ayat 34.

63 Abi Ja'far Muhammad bin jarir al Thabari, Jami' al Bayān 'an ta'wīl ayatil Qur'an, (Beirūt: Dār al Fikr, 2005), h. 2418.

64 Redaksinya: وذكر أن هذه الأية نزلت في رجل لطم امرأته فخوصم إلى النبي في ذلك فقضى لها بالقصاص 
beberapa riwayat yang sesuai dengan pendapat tersebut. Di antaranya:

$$
\begin{aligned}
& \text { حدتثي محمد بن بشار، قال: ثنا عبد الأعلى، قال: ثنا سعيد عن قتادة قال: ثنا } \\
& \text { الحسن: أن رجلا لطم امرأته فأتت النبي ص.م فأراد أن يقصها منه فأنزل الله }
\end{aligned}
$$

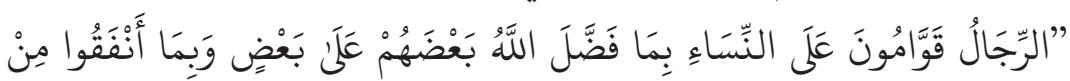

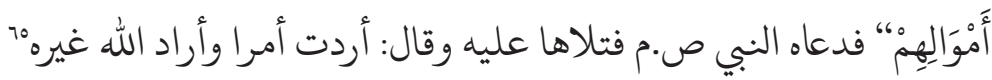

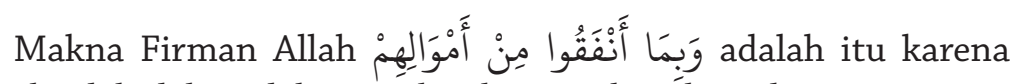
mereka laki-laki telah memberikan mahar kepada perempuan, serta menginfakkan nafkah kepada kaum perempuan. Lalu alThabari menyajikan riwayat-riwayat yang sesuai dengan pendapat tersebut. Dengan demikian maknanya adalah kaum laki-laki adalah pemimpin kaum wanita, karena Allah telah memberikan kelebihan kepada mereka dan karena mereka telah memberikan nafkah kepada kaum perempuan yang diambil dari sebagian harta mereka.

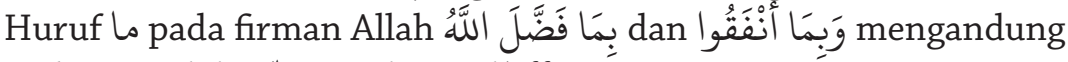
makna mashdar (L masdariyyah). ${ }^{66}$

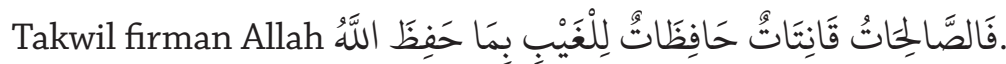
Makna firman Allah فالصالحات wanita yang shalih adalah wanitawanita yang lurus dalam menjalankan agama dan melakukan kebaikan, lalu al-Thabari menyajikan riwayat-riwayat yang sesuai dengan pendapat tersebut. Ada yang berpendapat bahwa maksud firman Allah قانتات adalah wanita-wanita yang taat kepada Allah dan suami-suaminya. Lalu al-Thabari menyebutkan riwayat-riwayat yَافِظَاتُ لِلفَغَيْب adalah wanita-wanita yang menjaga diri saat suaminya sedang tidak ada ditempat, baik dengan menjaga kemaluan, kehormatan dirinya, maupun harta suaminya serta memelihara dirinya dengan melaksanakan kewajiban-kewajibannya baik menyangkut hak Allah maupun hak lainnya. ${ }^{67}$ Lalu al-Thabari menyebutkan riwayatriwayat yang sesuai dengan pendapat tersebut.

65 Abi Ja'far Muhammad bin jarir al Thabari, Jami' al Bayān, h. 2419.

66 Abi Ja'far Muhammad bin jarir al Thabari, Jami' al Bayān, h. 2420.

67 Abi Ja'far Muhammad bin jarir al Thabari, Jami' al Bayān, h. 2421. 
Terjadi perbedaan pendapat qira'at dalam membaca firman Allah بِمَا حَفِظً الََّّ qira'at yang berlaku diberbagai belahan dunia Islam dengan rafa' lafaz Allah yang maknanya adalah dengan pemeliharaan Allah terhadap mereka sebab Allah telah membuat mereka menjadi seperti itu. Maksudnya yaitu dipelihara oleh dzatnya. Lalu alThabari menyebutkan riwayat-riwayat yang sesuai dengan pendapat tersebut. Abu Ja'far Yazid bin al Qa'qa' al Madani membacanya بِمَا حَفِظً اللَّهُ yang maknanya adalah karena mereka (istri-istri) memelihara Allah dengan menaati-Nya dan menunaikan hakNya sesuai dengan yang Allah perintahkan kepada mereka (yaitu memelihara diri ketika suami mereka sedang tidak ada di tempat). Qira'at yang benar untuk firman Allah tersebut adalah qira'at yang muncul tanpa mengandung cacat dan dapat ditetapkan hujjahnya. Qira'at yang benar adalah qira'at dengan rafa' nama Allah. ${ }^{68}$

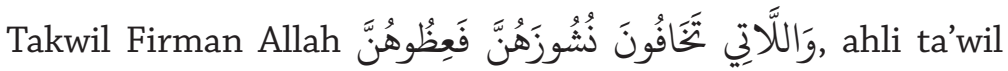
berbeda pendapat tentang makna firman Allah tersebut. Sebagian berpendapat bahwa maknanya adalah wanita-wanita yang kalian ketahui nusyuznya. Menurut mereka kata takut dirubah menjadi tahu, sebagaimana ucapan seorang penyair:

$$
\text { ولا تدفني في الفلاة فإنني \# أخاف إذا ما مت أن لا أذوقها }
$$

Jangan sekali-sekali engkau menguburku di tanah yang tandus, sesungguhnya aku takut, jika aku mati kelak, aku tidak akan dapat merasakannya (khamer) lagi. Maknanya adalah "sesungguhnya aku mengetahui".

Makna kata nusyuz pada firman Allah نشوزهن adalah kecongkakan mereka terhadap suami mereka, penghindaran mereka dari tempat tidur suami mereka dengan melakukan kemaksiatan, menyalahi suami mereka pada hal-hal yang diwajibkan oleh Allah kepada mereka untuk taat kepada suami mereka, kebencian mereka, dan keberpalingan mereka dari suami-suami mereka. Makna asal kata an-nusyuyz adalah al-Irtifä' (meninggi). Oleh karena itu, tempat yang tinggi disebutkan dengan nasyz dan Nasyaaz. ${ }^{69}$

68 Abi Ja'far Muhammad bin jarir al Thabari, Jami' al Bayān, h. 2423.

69 Abi Ja'far Muhammad bin jarir al Thabari, Jami' al Bayān, h. 2428. 
Makna firman-Nya فَفِظُوهُنَ adalah ingatkanlah mereka (kaum perempuan atau para istri kepada Allah dan takutilah mereka dengan ancaman Allah bila mereka melakukan hal-hal yang telah diharamkan Allah kepada mereka, padahal Allah telah mewajibkan mereka untuk taat kepada suami mereka.

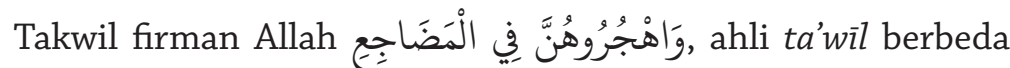
pendapat tentang makna firman Allah tersebut. Sebagian berpendapat bahwa makna firman Allah tersebut adalah "Wahai para suami nasehatilah mereka (istri-istri kalian) terkait dengan nusyuz yang mereka lakukan terhadap kalian. Jika mereka enggan kembalikepada kebenaran dalam halitu, sementara telah diwajibkan terhadap mereka atas kalian, maka pisahkanlah mereka dengan tidak menggauli mereka ditempat tidur kalian. Sementara ahli ta'wīl lainnya berpendapat bahwa maknanya adalah pisahkanlah mereka. Acuhkanlah mereka karena mereka tidak bersedia tidur bersama kalian, hingga mereka kembali ketempat tidur kalian.

Kata al hajr dalam bahasa Arab hanya memiliki salah satu dari tiga makna berikut ini:

1. Hajara ar-rajul kalāma ar-rajuli wa haditsahu (seseorang menolak dan tidak bicara dengan orang lain). Maksudnya dia menolah dan tidak berbicara dengan orang itu.

2. Banyak bicara dengan mengulang-ulang pembicaraan tersebut, seperti perkataan orang yang mengejek. Dikatakan Hajara Fūlanuhu fi kalāmihi hajrān (Fulan berbicara tidak karuan) dan memanjangkan kalimatnya.

3. Hajara al ba'iira (seseorang mengikat unta), maksudnya, pemiliknya mengikatnya dengan hijar yaitu tali yang diikatkan di kedua pahanya dan pergelangan kaki depannya. ${ }^{70}$

Dalam bahasa Arab, al-hajar hanya memiliki salah satu dari tiga makna tersebut. Jadi, suami dari seorang istri yang dikhawatirkan berbuat nusyuz hanya diperintahkan untuk mengingatkan istrinya agar taat kepada dirinya dalam hal-hal yang telah Allah wajibkan

70 Abi Ja'far Muhammad bin jarir al Thabari, Jami' al Bayān, h. 2428. 
kepada istrinya yaitu menyetujuinya bila ia mengajak istrinya itu ke tempat tidurnya.

Takwil firman Allah وَاضْرَبُوهُنَ maknanya adalah “wahai para suami, nasehatilah istri kalian tentang perbuatan nusyuz mereka. Jika mereka menolak untuk kembali kepada kewajiban mereka, yaitu taat kepada Allah, maka ikatlah mereka dengan tali, di rumah mereka dan pukullah mereka agar mereka kembali kepada kewajiban mereka yaitu taat kepada Allah dalam kewajiban mereka terkait dengan hak kalian. Sifat pukulan yang dobolehkan Allah kepada suami adalah pukulan yang tidak melukai. ${ }^{71}$

Takwil firman Allah فَإِنْ أَطْنْنَكُمْ فَلَا تَبْغُوا عَلَيْهِنَّ سَبِيلَ maknanya adalah "Wahai manusia, jika istri-istrimu yang kalian khawatirkan nusyuznya ketika kalian menasehati mereka, maka janganlah kamu memisahkan di tempat tidur mereka. Jika mereka tidak menaati kalian, maka pisahkanlah mereka di tempat tidur mereka dan pukullah mereka. Jika ketika itu mereka kembali menaati kalian dan kembali kepada kewajiban kalian, maka janganlah kalian mencari-cari jalan untuk menyakiti dan menyusahkan mereka dan janganlah kalian mencari-cari cara untuk meraih sesuatu yang tidak halal bagi kalian dari tubuh dan harta mereka dengan suatu alasan.

Takwil firman Allah إِنَّ اللَّهَ كَانَ عَلِيَّا كَبِيرِ maknanya adalah Allah berfirman sesungguhnya Allah Maha Tinggi atas segala sesuatu, maka janganlah kalian wahai manusia mencari-cari jalan untuk menyusahkan istri-istri kalian pada apa-apa yang Allah wajibkan kepada mereka terhadap hak kalian. ${ }^{72}$

\section{G. KESIMPULAN}

Metode tafsir tahlīlī dalam perkembangannya dianggap muncul setelah metode ijmālì karena pada masa sahabat, mayoritas sahabat tidak membutuhkan penjelasan yang rinci, hal tersebut disebabkan kemampuan bahasa Arab sahabat yang memadai sehingga tidak memiliki kesulitan dalam memahami ayat al-

71 Abi Ja'far Muhammad bin jarir al Thabari, Jami' al Bayān, h. 2431.

72 Abi Ja'far Muhammad bin jarir al Thabari, Jami' al Bayān, h. 2434. 
Qur'an dan banyak para sahabat yang menyaksikan bahkan terlibat langsung dengan kondisi saat ayat al-Qur'an diturunkan. Namun seiring perkembangan zaman, umat Islam jumlahnya semakin bertambah tidak hanya dari orang Arab tapi juga non-Arab yang membutuhkan penjelasan petunjuk al-Qur'an secara lebih rinci. Oleh karena itu Metode taḥlīli hadir menyajikan tafsir al-Qur'an berdasarkan urutan ayat-ayat al-Qur'an dalam mushaf ditinjau dari berbagai aspeknya. Jadi, metode tafsir tahlīin ini dibagi oleh beberapa ulama menjadi beberapa macam, yaitu tafsir bi al-Ma'tsūr, bi al-Ra'yi, Shūfì, Fiqhī, Falsafì, 'Ilmī, dan Adabì al-Ijtimā̄ì. Semua bentuk tafsir tahlīlī memiliki ciri khasnya sendiri-sendiri. Tafsir bi al ma'tsūr adalah tafsir yang penafsirannya dengan menggunakan ayat-ayat lain, riwayah Nabi SAW, sahabat, dan tabi'in. Tafsir bi al-ra'yi adalah tafsir yang penafsirannya menggunakan metode ijtihad dan penalaran. Tafsir shufi adalah tafsir yang menekankan pada isyarat-isyarat yang terdapat pada ayat yang dikemukakan oleh tasawuf. Tafsir fiqhī adalah tafsir yang menekankan pada tinjauan hukum dari ayat yang ditafsir. Tafsir falsafi adalah tafsir yang menafsirkan al-Qur'an dengan pendekatan filsafat. Tafsir 'ilmì adalah tafsir yang menggunakan pendekatan ilmiah atau teori-teori ilmu pengetahuan. Tafsir yang terakhir adalah adabi alijtimā' kemasyarakatan. Tafsir tahlīlī jika dibandingkan dengan metode tafsir lainnya memiliki ciri khusus, ciri-ciri tersebut adalah: Pertama, Para Mufasir menafsirkan ayat per ayat sesuai dengan urutan dalam mushaf utsmani, yaitu dimulai dari surat Al-Fatihah dan diakhiri oleh surat an-Nas. Kedua, Para Mufasir menjelaskan makna yang terkandung dalam al-Qur'an secara komprehensif dan menyeluruh, baik makna harfiah setiap kata maupun asbābun nuzulnya. Ketiga, Jika dilihat Bahasa yang digunakan metode tậlīì tidak sesederhana yang dipakai metode tafsir ijmālì.

Seperti halnya metode tafsir yang lain, metode tafsif tahlìlì ini juga memiliki beberapa kelebihan dan kekurangan. Di antara kelebihan tafsir ini adalah ruang lingkupnya luas, memuat berbagai ide dan masih banyak lagi kelebihan dari tafsir ini. Sementara itu di antara kekurangan metode ini yaitu al-Qur'an sebagai 
petunjuk terlihat menjadi parsial, menghasilkan penafsiran yang subyektif, masuknya pemikiran isra'iliat, dan lain-lain. Dalam sejarahnya Metode tafsir tahlili dalam dunia Islam dimulai sejak ditulisnya tafsir Jamīul Bayān fī Tafsīr al-Qur'ān karya Ibnu Jarir at-Thabari. Karya at-Thabari ini dianggap sebagai tafsir tertua yang menggunakan metode tahlili. Imam at-Thabari dalam menjelaskan ayat-ayat demi ayat dengan menunjuk kepada Hadist Nabi, ucapan sahabat, aspek kebahasaan dan bebeberapa sumber lainnya untuk menjelaskan ayat tersebut. Upaya penafsiran seperti ini kemudian banyak diikuti oleh mufassir lain seperti Ibnu Katsir dan asSuyuthi.[] 


\section{DAFTAR PUSTAKA}

Anwar, Roshian, Ilmu Tafsir, Bandung: Pustaka Setia, 2005.

Azizy, Faizah Ali Syibromalisi dan Jauhar. Membahas Kitab Tafsir Klasik-Modern. Jakarta: Lembaga Penelitian UIN Syarif Hidayatullah Jakarta, 2011.

Baalbaki, Rohi, al-Mawrid: A Modern Arabic-English Dictionary. Beirut: Dar el 'Ilm lil Malayin, 1995.

Adz-Dzahabi, Muhammad Husain, al Tafsīr wa al-Mufassirūn. Mesir: Dār al-Kutub al-Haditsah, 1976), Jilid. 1, cet. 2.

Al-Farmawi, Abd Hayy. al-Bidāyah fi al-Tafsīr al-Maudhū'i: Dirāsah Manhajiyyah Maudhūiyyah. terjemahan Rosihon Anwar, Metode Tafsir Maudhü'I Dan Cara Penerapannya. Bandung: Pustaka Setia, 2002.

Hamid, Muhsin Abd, Tathawwur tafsīr al-Qur'an, Dārul Kutub wa an-Nasyar, 1989.

Hanafi, Hasan, Islam in the Modern World: Vol. 1 Religion, Ideologi and Development. Heliopolis: Dar Kebaa Bookshop, 2000.

Ibrahim, Malik, "Corak dan Pendekatan Tafsir al-Qur'an", dalam Sosio Religia, vol 9, nomor 3 Mei 2010.

Isawi, Nasharuddin Baidan. Metodologi Penafsiran al-Qur'an. Jakarta: Pustaka pelajar, 1998.

Khaeruman, Badri, Sejarah Perkembangan Tafsir al-Qur'an. Bandung: CV Pustaka Setia, 2004.

Kholis, Nur, Pengantar Al-Qur'an dan Hadis, Yogyakarta: Sukses offset, 2008

Muhammad bin Mukrim bin Ali Abu al-Fadil Jamaluddin bin Manzur, Lisān al-'Arabi, Juz 11, Beirut: Dār Sadir, 1414 H.

Pari, Fariz, "Tafsir sebagai Hermeneutika Islam: Kajian dan Terapan" dalam Pengantar Kajian al-Qur'an, Kusmana dan Syamsuri (ed). Jakarta: Pustaka al-Husna Baru, 2004.

Rohimin, Metodologi Ilmu Tafsir dan Aplikasi Model Penafsiran, Yogyakarta: Pustaka Belajar, 2007 
Saeful Rokim, "Mengenal Metode tafsir tahlilī”, Jurnal staialhidayah, Bogor, 2017.

Saleh, Ahmad Syukri, Metodologi Tafsir al-Qur'an Kontemporer dalam Pandangan Fazlur Rahman. Jakarta: Gaung Persada Press, 2007.

Sanaky, Hujair A. H., "Metode Tafsir(Perkembangan Metode Tafsirmengikuti warna atau corak mufassirin", Almawarid,vol.18, 2018.

Al-Shadr, Muhammad Baqir, al Tafsīr al Maudhūi wa al-Tafsìr alTajzii fil Qur'anil karìm. Beirut: Dar al Ta'aruf, tt.

Shihab, M. Quraish, dkk. Sejarah dan 'Ulum al-Qur'an. Jakarta: Pustaka Firdaus, 2008.

, Kaidah Tafsir: Syarat, Ketentuan, dan Aturan yang Patut Anda Ketahui dalam Memahami Ayat-Ayat al-Qur'an. Jakarta: Lentera Hati, 2013. , Membumikan al-Qur'an: Fungsi dan Peran Wahyu dalam kehidupan Masyarakat, Bandung: Mizan, 1992.

Supiana dan M. Karman, 'Ulumul Qur'an dan Pengenalan Metodologi Tafsir, Bandung: Pustaka Islamika, 2012.

Syafi'i, Rachmat, Pengantar Ilmu Tafsir, Bandung: Pustaka SETIA, 2006.

Ath-Thabari, Abi Ja'far Muhammad bin Jarir, Jami' al Bāyan 'an ta'wīl ayatil Qur'an. Beirut: Dar al Fikr, 2005.

Zakariya, Ahmad bin Faris bin, Mu’jam Maqāyis al-Lugah. Juz 2, Beirut: Dār al-Fikr, 1999.

Al-Zarkasyi, Badr al-Din, al Burhān fi 'ulūm al-Qur'an. Beirut: Dār alKutub al 'Ilmiyahh,1988), Jilid 1.

Al-Zarqani, Abd al 'Azhim, Manāhil al-Irfan fi 'Ulum al-Qur'an. Mesir: Mustafa al-Babi al-Halabi, t.th), Jilid II.

Zuailan, "Metode Tafsir Taḥlìlī", dalam Diya al-Afkar, vol.iv, no.01, Juni 2016. 